\title{
Results of penetrating keratoplasty for pseudophakic bullous keratopathy with the exchange of an intraocular lens
}

\author{
T L VAN DER SCHAFT, G VAN RIJ, J G C RENARDEL DE LAVALETTE, \\ AND W H BEEKHUIS
}

From the 'Department of Ophthalmology, Erasmus University, Eye Hospital, Rotterdam, The Netherlands

SUMMARY We report on 29 consecutive patients with pseudophakic bullous keratopathy who underwent in one eye penetrating keratoplasty with an exchange of the original intraocular lens for a Pearce tripod posterior chamber lens, and who were available for a follow up of at least 12 months. The average interval between cataract extraction with lens implantation and the appearance of bullous keratopathy was five and a half years (range 10 months to 16 years). The mean follow-up period after penetrating keratoplasty was 36 months (range 12 to 56 months). The corneal graft remained clear in $22(76 \%)$ eyes. One year after the operation $45 \%$ of the eyes had a vision of $20 / 40$ or better, and $20 \%$ had visual acuities between $20 / 40$ and $20 / 100$. The remaining $31 \%$ had a vision of $20 / 100$ or less (one unknown). Nine eyes $(31 \%)$ had cystoid macular oedema or macular degeneration. $45 \%$ of the eyes had a refraction within approximately 2 dioptres of emmetropia. In patients with pseudophakic corneal oedema we continue to exchange the intraocular lens by a Pearce tripod posterior chamber lens sutured to the iris when it is necessary to remove the lens.

Pseudophakic corneal oedema is now the most common indication for penetrating keratoplasty in the United States. ${ }^{1-\infty}$ Patients who underwent cataract extraction with implantation of an iris supported intraocular lens (IOL) still form the largest group of patients undergoing penetrating keratoplasty in The Netherlands.

Several authors have previously reported the results of keratoplasty in patients with pseudophakic bullous keratopathy from whom the intraocular lens was removed, retained, or exchanged.

Before 1980 we removed or retained and fixated the iris supported IOLs to the iris, the decision depending on the decentration or movements of the IOL, erosive iris atrophy, and other pathological states of the eye. We found that after removing the IOL many elderly monocular aphakes could be fitted with a contact lens, but that they discontinued use of the lens after some time despite good vision. We therefore began exchanging the iris supported intraCorrespondence to G van Rij, MD, Eye Hospital, Schiedamsevest 180, 3011 BH Rotterdam, The Netherlands. ocular lens in the anterior chamber, at first, for a Pearce bipod posterior chamber lens and then, from 1982 on, with a Pearce tripod posterior chamber lens sutured to the iris when it was necessary to remove the iris supported IOL. If the intraocular lens was well fixated and well positioned in the eye, particularly after an extracapsular lens extraction, and in our opinion not the cause of the corneal oedema, we left the lens in place.

In this study we evaluate our results of penetrating keratoplasty for pseudophakic bullous keratopathy with exchange of intraocular lens using a Pearce tripod posterior chamber lens sutured to the posterior iris.

\section{Patients and methods}

We studied retrospectively the clinical records of 32 consecutive patients with pseudophakic bullous keratopathy who between January 1982 and May 1986 underwent a penetrating keratoplasty with exchange of intraocular lenses by a Pearce tripod posterior 
chamber lens. All eyes had moderate to severe irreversible corneal oedema with or without bullae. The intraocular pressure was within normal limits before surgery, though six eyes needed medication for glaucoma. One eye had cystoid macular oedema before the operation, proved by fluorescein angiography. If the retina could not be examined with the ophthalmoscope before the operation, an electroretinogram (ERG) was made, and the visually evoked potentials (VEP) measured. All patients were operated on by one of the three corneal surgeons in the Rotterdam Eye Hospital, all three using the same technique. Of these patients $62 \%$ were women, ranging in age from 57 to 92 years, mean 78 years. The age of the men ranged from 45 to 87 years, mean 72 years. Three patients were unavailable for followup of at least 12 months. Two patients died, and one patient was unavailable for follow-up. We report on the remaining 29 patients whose cases were followed up after surgery for a period of 12 to 56 months, mean 36 months.

\section{SURGICAL TECHNIQUE}

The pupil was neither constricted nor dilated before surgery with the patient under general or local anaesthesia. A single Flieringa ring was sutured to the episclera with six 7-0 silk sutures. Gentamicin 0.5 $\mathrm{ml}$ was administered subconjunctivally outside the ring. Trephination was performed with a free trephine blade without handle or obturator. ${ }^{78}$ The diameter of the trephine blade ranged from 7.0 to $8.5 \mathrm{~mm}$. A diameter of 7.5 and $8.0 \mathrm{~mm}$ was used in, respectively, $34 \%$ and $45 \%$ of the eyes. The iris supported IOL was removed and an anterior vitrectomy was done with cellulose sponges and scissors if there was a prolapse of the vitreous into the pupil or incarceration of vitreous in the cataract wound (13 eyes). In some eyes haptics were amputated first and adhesions between iris, vitreous, and IOL were dissected. This was done carefully with the least possible trauma to the ocular structures.

At the same time the assisting surgeon knotted a single armed 10-0 prolene suture to each of the three holes of the iris stitch Pearce tripod lens with 10-15 knots leaving a small loop of the prolene suture through the hole of the lens ${ }^{y}$ (Fig. 1). This allows a tolerance for a slightly misplaced suture and prevents pulling of the knot through the iris. The lens was placed on the peripheral corneal rim and the two sutures, tied to the inferior holes of the lens, were passed through the pupil and from posteriorly through the iris half way between pupil and the angle. Then the IOL was placed behind the iris, and, if necessary, iridoplasty was performed with a 10-0 polypropylene suture. The 12 o'clock fixation suture was passed through the pupil and from posteriorly through the

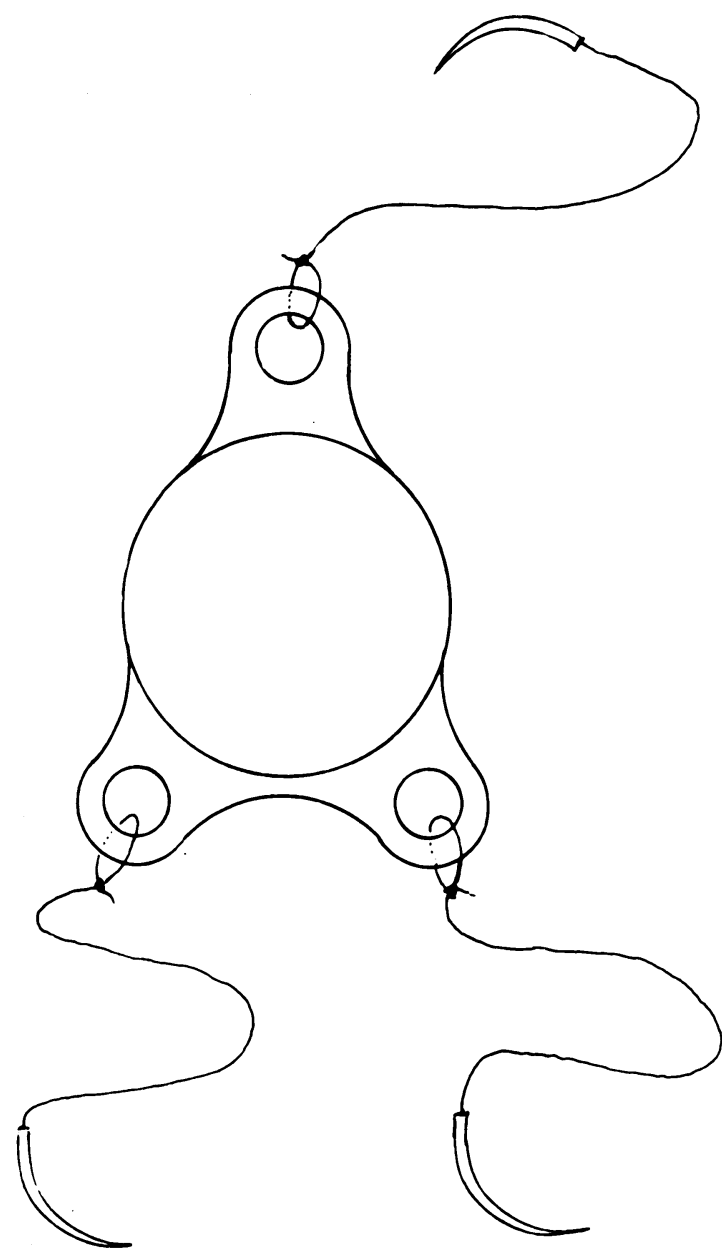

Fig. 1 Pearce tripod lens with three prolene sutures knotted to the holes of the lens.

iris, and the three sutures were pulled gently to check if the lens was properly placed. The sutures were fixed to the iris with a second pass through the anterior surface of the iris, and then secured with a knot.

Initially the power of the tripod lens was calculated with the Binkhorst formula from axial length measurement of the pseudophakic eye and keratometry of the other eye. After myopic surprises we started using the average postoperative keratometry readings from the previous series of penetrating keratoplasties for pseudophakic and aphakic corneal oedema."

Donor tissue stored in McCarey-Kaufman medium was used within 48 hours of preservation. A new disposable razor blade trephine, $0.5 \mathrm{~mm}$ larger in diameter than the host trephine, was used to punch out the donor button from the endothelial side of the 
cornea on a Teflon block." Before 1983 the donor corneal button was then sutured to the host cornea with a single running 10-0. From 1983 it was sutured with eight interrupted $10-0$ and a running 11-0 nylon suture. ${ }^{12}$ At the end of the procedure a subconjunctival injection of soluble corticosteroid was given.

After surgery antibiotics and tapering doses of topical corticosteroids were administered, with most patients being maintained on a regimen of a daily dose of one drop of dexamethasone $0 \cdot 1 \%$.

\section{Results}

The interval between and the implantation of the first intraocular lens after lens extraction and the first appearance of bullous keratopathy ranged from 10 months to 16 years, mean $51 / 2$ years (SD $4 \cdot 5$ years). In all patients the first intraocular lens was an iris supported lens, implanted after an intracapsular cataract extraction in 59\% and after an extracapsular extraction in $41 \%$ of the cases. The criteria for removal of the intraocular lens are specified in Table 1.

Complications immediately after operation were a mild hyphaema (one eye), vitreous prolapse in the

Table 1 Indication for removal, and type of intraocular lens removed, during penetrating keratoplasty in 29 eyes with pseudophakic corneal oedema.

\begin{tabular}{|c|c|c|c|c|}
\hline & \multicolumn{2}{|c|}{$\begin{array}{l}\text { Intracapsular cataract } \\
\text { extraction }(n=17)\end{array}$} & \multicolumn{2}{|c|}{$\begin{array}{l}\text { Extracapsular cataract } \\
\text { extraction }(n=12)\end{array}$} \\
\hline & $\begin{array}{l}\text { Binkhorst } \\
4 \text { loop }\end{array}$ & $\begin{array}{l}\text { Worst } \\
\text { medallion }\end{array}$ & $\begin{array}{l}\text { Binkhorst } \\
2 \text { loop }\end{array}$ & \\
\hline Malposition & 4 & 2 & 7 & $(45 \%)$ \\
\hline Endothelium touch & 1 & 3 & 1 & $(17 \%)$ \\
\hline Excess lens & & & & \\
\hline movements & 2 & 1 & & $(10 \%)$ \\
\hline $\begin{array}{l}\text { Retrolental } \\
\text { membrane }\end{array}$ & & 1 & & $(3 \%)$ \\
\hline Not specified & 2 & 1 & 4 & $(24 \%)$ \\
\hline Total number & 9 & 8 & 12 & \\
\hline
\end{tabular}

Table 2 Postoperative complications after penetrating keratoplasty with exchange of the intraocular lens

\begin{tabular}{lc}
\hline Late complications $^{*}$ & No. \\
\hline Cloudy cornea & 7 \\
Cystoid macular oedema & 3 \\
Macular degeneration & 6 \\
Partly dehiscent graft & 2 \\
Posterior capsule haze & 1 \\
Persistent postoperative pain & 1 \\
Retinal detachment & 1 \\
\hline
\end{tabular}

*Frequently more than one complication in one eye.
CORNEAL GRAFT

SURVIVAL IN \%

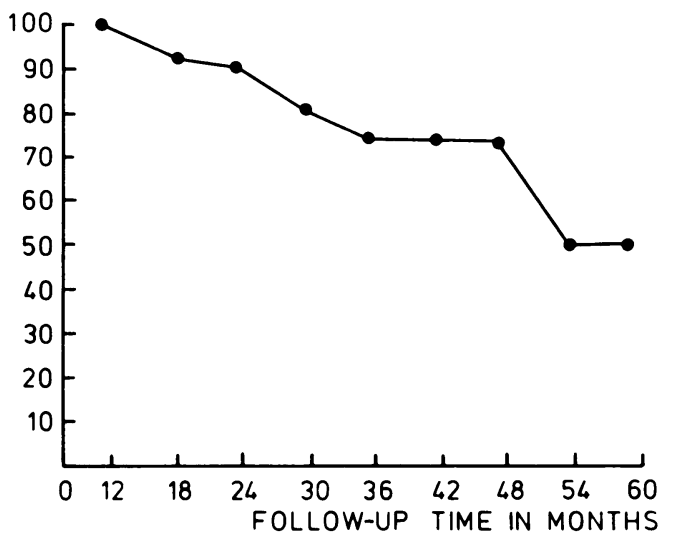

Fig. 2 Corneal graft survival curve after penetrating keratoplasty with an exchange of the intraocular lens.

anterior chamber (one eye), and slow re-epithelialisation of the cornea (two eyes). There were no cases of primary graft failure. Long-term complications are summarised in Table 2.

One patient developed a persistent corneal ulcer eight months after keratoplasty, and the cornea was covered with a conjunctival flap. ${ }^{13}$ Apart from this patient all other corneal transplants remained clear during the first 12 months of the follow-up period. The graft survival curve is shown in Fig. 2. After an average of 29 months (range 16 to 54 months, SD 13 months) seven grafts $(24 \%)$ opacified. Three grafts opacified owing to an irreversible graft rejection and two slowly opacified without obvious reason. One patient developed a silicone oil keratopathy due to silicone oil in the anterior chamber after a retinal detachment. ${ }^{14}$ In one patient with severe persistent postoperative pain and cystoid macular oedema the clear graft and the still oedematous peripheral rim of the recipient cornea were covered with conjunctiva. ${ }^{13}$

The visual acuities after the operations are shown in Table 3. Of the 15 eyes that did not achieve a visual

Table 3 Visual acuity after penetrating keratoplasty with intraocular lens exchange

\begin{tabular}{lllll}
\hline Visual acuity & $\begin{array}{l}20 / 40 \\
\text { or more }\end{array}$ & $\begin{array}{l}20 / 40 \\
-20 / 100\end{array}$ & $\begin{array}{l}20 / 100 \\
\text { or less }\end{array}$ & Unknown \\
\hline $\begin{array}{l}\text { One year } \\
\text { postoperative }\end{array}$ & $13(45 \%)$ & $6(20 \%)$ & $9(31 \%)$ & $1(3 \%)$ \\
$\begin{array}{l}\text { Most recent } \\
\begin{array}{l}\text { Best postoperative } \\
\text { ever }\end{array}\end{array}$ & $12(41 \%)$ & $4(14 \%)$ & $11(38 \%)$ & $2(7 \%)$ \\
\hline
\end{tabular}


acuity of $20 / 40$ or more three had cystoid macular oedema, one eye had a conjunctival flap, and six had macular abnormalities. In five eyes the reasons for poor visual acuities remained unknown or were not mentioned in the clinical records.

There was no difference in visual acuity between the eyes in which an anterior vitrectomy was performed during keratoplasty and those without vitrectomy.

The mean spherical equivalent of the most recent refraction was -2.4 dioptres (range +3 to -10 , SD $4 \cdot 1) .45 \%$ of the eyes had a refraction within approximately 2.0 dioptres of emmetropia. Corneal astigmatism, measured one year after operation, showed a mean of 5.6 dioptres (range 1 to 8, SD 3.9). The mean keratometry one year after keratoplasty was 48 dioptres (range 42.7 to 52.5 dioptres). Because most eyes still had some of the interrupted $10-0$ nylon corneal sutures in place at the time these measurements were taken, the refractions and visual acuities may differ when all sutures are removed.

Six eyes with raised intraocular pressure were controlled medically before the operation. Intraocular pressure was raised in 13 eyes $(46 \%)$ after the keratoplasty. Eight of these eyes $(66 \%)$ had a visual acuity of $20 / 40$ or better. In two eyes the intraocular pressure, which was too high before operation, was normal after keratoplasty. Two eyes with a raised intraocular pressure had paracentral scotoma. In only one eye could the pressure not be controlled with medication and we therefore performed cyclocryocoagulation.

\section{Discussion}

Our results show that pseudophakic corneal oedema appeared on an average $5 \frac{1}{2}$ years after cataract extraction, SD $4 \frac{1}{2}$ years. Other authors mention an average period between five months and $4 \frac{1}{2}$ years. ${ }^{2356}$

In The Netherlands intraocular lenses have been implanted for more than 20 years. In some cases corneal oedema appears long after the operation has taken place. In one case the pseudophakic corneal oedema appeared after 16 years. This may explain the longer time lapse from lens implantation to onset of corneal oedema found in our study.

Of the grafts reported on here $97 \%$ remained clear during the first 12 months. Later seven grafts (24\%) opacified. Five of these showed pseudophakic corneal oedema, which occured an average of 29 months after the keratoplasty. Other studies have reported the development of pseudophakic corneal oedema in the graft in 9 to $20 \%$ of cases, with a mean follow-up of less than two years (Tables 4, 5). As several authors have shown that, following kerato- plasty for pseudophakic bullous keratopathy, a progressive loss of endothelial cells occurs, it is most likely that the number of eyes with corneal decompensation will increase with a longer follow-up period. ${ }^{\text {is }}$ The mean follow-up period in our study was 36 months, SD 14 months.

All patients had an iris supported intraocular lens implanted, and the main complication we found was malposition and excessive movement of the lens, which resulted in a bullous keratopathy and low visual acuity. In some cases the appearance of bullous keratopathy may have been due to chronic low-grade uveitis. ${ }^{16}$

Before 1980 we removed or retained and fixed the iris supported IOLs to the iris, depending on the decentration or movements of the IOL, iris atrophy, the uveitis-glaucoma-hyphaema syndrome and other pathology of the eye. This was a very controversial subject at that time, and other studies were difficult to compare with ours because the study population and surgical technique varied, and the criteria for retention or removal were not specified. Some surgeons removed all implants, while others tried to retain them when possible. Without sodium hyaluronate it was technically difficult safely to suture the donor button over an iris supported implant. We started first to exchange the iris supported intraocular lens in the anterior chamber for a Pearce bipod posterior chamber lens and from 1982 on, for a

Table 4 Results after penetrating keratoplasty for pseudophakic bullous keratopathy

\begin{tabular}{|c|c|c|c|c|}
\hline Author & $\begin{array}{l}\text { No. of } \\
\text { eyes }\end{array}$ & $\begin{array}{l}\text { Follow-up } \\
\text { (months) }\end{array}$ & $\begin{array}{l}\text { IOL } \\
\text { removal }\end{array}$ & $\begin{array}{l}\text { Clear } \\
\text { grafts }\end{array}$ \\
\hline Taylor et al. ${ }^{2}$ & 42 & $\begin{array}{l}1-51 \\
\text { (mean 14.8) }\end{array}$ & $7 / 42$ & $88 \%$ \\
\hline Waring et al. ${ }^{+}$ & 25 & $\begin{array}{l}12-38 \\
\text { (mean 18.7) }\end{array}$ & $\begin{array}{l}25 / 25 \\
\text { exchanged }\end{array}$ & $88 \%$ \\
\hline Waring et al. ${ }^{3}$ & 35 & (mean $14 \cdot 8)$ & $35 / 35$ & $91 \%$ \\
\hline Meyer and Sugar.` & 25 & $\begin{array}{l}6-41 \\
(\text { mean 20) }\end{array}$ & $11 / 25$ & $88 \%$ \\
\hline vd Schaft et al. & 29 & $\begin{array}{l}12-56 \\
\text { (mean 36) }\end{array}$ & $\begin{array}{l}\text { All } \\
\text { exchanged }\end{array}$ & $83 \%$ \\
\hline
\end{tabular}

Table 5 Results after penetrating keratoplasty for pseudophakic bullous keratopathy

\begin{tabular}{cclll}
\hline $\begin{array}{l}\text { Corneal } \\
\text { macular } \\
\text { oedema }\end{array}$ & $\begin{array}{l}\text { Macular } \\
\text { degeneration }\end{array}$ & $\begin{array}{l}\text { VA 20/40 } \\
\text { or more }\end{array}$ & $\begin{array}{l}\text { VA 20/40 } \\
-20 / 100\end{array}$ & $\begin{array}{l}\text { VA 20/100 } \\
\text { or less }\end{array}$ \\
\hline $6 \%$ & $11 \%$ & $32 \%$ & $19 \%$ & $49 \%$ \\
$37 \cdot 5 \%$ & $12 \%$ & $36 \%$ & $46 \%$ & $18 \%$ \\
$43 \%$ & $17 \%$ & $60 \%$ & $23 \%$ \\
$24 \%$ & $8 \%$ & $52 \%$ & $16 \%$ & $32 \%$ \\
$10 \%$ & $21 \%$ & $41 \%$ & $14 \%$ & $38 \%$ \\
\hline
\end{tabular}


Pearce tripod lens sutured to the iris, when it was necessary to remove the iris supported lens." A lens in the posterior chamber sutured to the iris made it much easier to suture the donor button in the recipient cornea safely. Sodium hyaluronate has made surgery less complicated, but does not change the indications for retaining or exchanging an intraocular lens. The lens is retained if properly fixed in the eye and if not affected by intraocular inflammation.

There were few intra- and postoperative complications, and the longer term complications were mainly bullous keratopathy $(17 \%)$, macular degenerations $(20 \%)$, and cystoid macular oedema $(10 \%)$. It was not known whether the last two complications existed before the operation (Table 2). Corneal oedema frequently makes preoperative examination of the retina difficult.

Visual acuity (Table 3) after keratoplasty and lens exchange improved in $65 \%$, and in $31 \%$ there was no improvement. We always inform our patients carefully that macular disease may be present. ${ }^{17}$

It was difficult in our study to demonstrate a strong correlation between the development of cystoid macular oedema and anterior vitrectomy during operation, though other authors have suggested or demonstrated that anterior vitrectomy induces it to develop. ${ }^{18}$

There was no correlation between a postoperative high intraocular pressure and the visual outcome, though two eyes developed paracentral scotoma. A raised intraocular pressure was not a rare complication, but in all but one eye it was successfully lowered with medication. The incidence of postoperative raised intraocular pressure might be reduced by performing gonioplasty during penetrating keratoplasty. ${ }^{4}$

In our study the earliest postoperative refraction was within the range of 2 dioptres of emmetropia in only $45 \%$ of the eyes.

\section{References}

1 Robin JB, Gindi IJ, Kok K, et al. An update of the indications for penetrating keratoplasty, 1979-1983. Arch Ophthalmol 1986: 104: 87-9.

2 Taylor DM, Atlas BF, Romanchuk KG, Stern AL. Pseudophakic bullous keratopathy. Ophthalmology 1983; 90: 19-24.

3 Waring GO, Welch SN, Cavanagh HD. Wilson LA. Results of penetrating keratoplasty in 123 eyes with pseudophakic or aphakic corneal edema. Ophthalmology 1983; 90: 25-33.

4 Waring GO, Stulting RD, Street D. Penetrating keratoplasty for pseudophakic corneal edema with exchange of intraocular lenses. Arch Ophthalmol 1987: 105: 58-62.

$5 \mathrm{Kaz}$ Soong H, Meyer RF, Sugar A. Posterior chamber IOL implantation during keratoplasty for aphakic or pseudophakic corneal edema. Cornea 1987: 6: 306-12.

6 Meyer RF, Sugar A. Penetrating keratoplasty in pseudophakic bullous keratopathy. Am J Ophthalmol 1980; 90: 677-81.

7 Tilanus M, van Rij G. An experimental comparison of three methods for trephination of the cornea and the consequent variations in the configurations of the trephine openings. Gracfes Arch Clin Exp Ophthalmol 1987: 225: 50-2.

8 van Rij G, Waring GO III. Configuration of corneal trephine opening using five different trephines in human donor eyes. Arch Ophthalmol 1988; 106: 1228-33.

9 Drews RC. The Pearce tripod posterior chamber intraocular lens: an independent analysis of Pearce's results. J Am Intraocul Implant Soc 1980; 6: 259-62.

10 Binder PS. Intraocular lens powers used in the triple procedure: effect on visual acuity and refractive error. Ophthalmology 1985; 92: $1561-6$.

11 van Rij G, de Ruiter W, Vijfvinkel G. Corneal punch block for disposable superblade trephine. Am J Ophthalmol 1983; 95: 564-5.

12 Binder PS. Selective suture removal can reduce postkeratoplasty astigmatism. Ophthalmology 1985; 92: 1412-6.

13 van Rij G, Rinkel-van Driel B, Beekhuis WH, Renardel de Lavalette JGC. Conjunctival transplantation. Doc Ophthalmol 1987: 67: 145-51.

14 Beekhuis WH, van Rij G, Zivojnovic R. Silicone oil keratopathy indications for keratoplasty. Br J Ophthalmol 1985; 69: 247-53.

15 Culbertson WW, Abbott RL, Foster RK. Endothelial cell loss in penetrating keratoplasty. Ophthalmology 1982; 89: 6()()-4.

16 Rao GN, Stevens RE, Harris JK, Aquavella JV. Long term changes in corneal endothelium following intraocular lens implantation. Ophthalmology 1981; 88: 386-97.

17 Stark WJ, Maumenee AE, Fagadau W. Cystoid macular edema in pseudophakia. Surv Ophthalmol 1984: 28: (suppl): 442-51.

18 Kramer SG. Cystoid macular edema after aphakic penetrating keratoplasty. Ophthalmology 1981; 88: 782-7.

Accepted for publication 3 April 1989. 